\title{
Endogenous Amino Acid Loss and Its Significance in Infantile Diarrhea
}

\author{
H. Ghadimi ${ }^{[33]}$, S. Kumar, and F. Abagi \\ Department of Pediatrics, Methodist Hospital of Brooklyn, and Downstate Medical Center, State University Hospital, \\ Brooklyn, New York, USA
}

\begin{abstract}
Extract
Significant amino acid loss through the stool, analogous to impeded reabsorption of water, fat, and electrolytes, was suspected in infantile diarrhea. The stools of six patients, who had acute diarrhea and received no protein by mouth, were collected and analyzed for amino acids, nitrogen, and protein. Similar determinations were made on five normal controls. In addition, stool collections were made from one patient during a severe protracted diarrhea which necessitated parenteral alimentation, during a subsequent isolated acute episode of diarrhea, and after complete recovery. The results of the analyses showed that free amino acids in the stool are elevated up to 10 -fold during diarrhea, as compared with periods of remission and with normal controls. Protein and total nitrogen excretion is also elevated in diarrhea, although to a lesser degree (4- and 2.5-fold, respectively). It is postulated that protracted diarrhea is associated with impaired reabsorption of endogenous nitrogen, which results in a vicious cycle of protein depletion that ultimately leads to an intractable stage. The validity of this assumption is confirmed by the success achieved by parenteral amino acid therapy for protracted diarrhea.
\end{abstract}

\section{Speculation}

It is postulated that intestinal mucosa and digestive enzymes, because of their large volume and rapid turnover, are extremely vulnerable to early states of protein deficiency. It is suggested that continuous loss of nitrogenous substances of endogenous origin occurs in protracted diarrhea, resulting in impaired synthesis of intestinal mucosa and digestive enzymes. The ensuing vicious cycle may be responsible for precipitating protracted diarrhea, regardless of etiology, into an intractable stage

\section{Introduction}

The term "intractable diarrhea" was first coined by Avery et al. [1] with reference to infants with protracted diarrhea which resisted therapy and which could not be encompassed by any conventional diagnostic category. Avery's patients met the following criteria: they were infants under 3 months of age, their diarrhea lasted at least 2 weeks, and repeated stool cultures were negative for a number of common pathogenic organisms. Although by definition, intractable diarrhea would be uniformly fatal, Avery and his coworkers reported a mortality rate of $45 \%$.

Other adjectives commonly used to describe longterm, resistant diarrhea in infancy include "protracted," "chronic," "idiopathic," and "nonspecific." As the terminology implies, therapy is unsatisfactory; the underlying pathophysiology of chronic diarrhea re- 
mains to be elucidated, and the point at which chronic diarrhea passes into the intractable stage remains unknown. It has been known for some time that large amounts of nitrogenous material of endogenous origin participate in the processes of digestion, hydrolysis, and absorption. But the failure to reabsorb such endogenous nitrogen has received little attention, even though such impeded reabsorption clearly has important ramifications for the body's protein economy. This pilot study was designed to explore the role played by the loss of endogenous amino acids through the stool in protracted diarrhea, and to examine the effect of intravenous amino acid administration on the course of the disease.

\section{Material and Methods}

Eight 24-hr stool collections were made on six patients with acute diarrhea. These samples, as well as all subsequent stool collections described in this paper, were analyzed for amino acids, protein, and total nitrogen. The diarrhea was considered mild to moderate, and the number of bowel movements varied from three to nine during the collection period. The consistency of the stool was characterized as pasty to watery. All patients were on nonprotein intake or glucose and water at least $24 \mathrm{hr}$ before the start of stool collection and also during the collection period, and thus did not receive any protein-containing food. Data from the infants with diarrhea were compared with corresponding values from five healty infants who served as control subjects. Stool collections from an additional patient who underwent parenteral alimentation were also analyzed.

This patient was admitted to the hospital at 3 weeks of age because of acute diarrhea, vomiting, dehydration, and acidosis. The patient failed to respond to conventional therapy and developed hemolytic-uremic syndrome. The therapeutic armamentarium used for the complicated clinical picture included repeated transfusions, corticosteroids, antibiotics, trial feeding of CHO-free milk, and Vivonex [31]. The diarrhea and weight loss continued. Three weeks after admission, the infant's weight had fallen below birth weight and parenteral alimentation was instituted. The procedure had to be continued for 85 days. Several attempts to reintroduce oral feeding (milk, CHO-free milk, Vivonex, glucose, and water) during this period resulted in exacerbation of diarrhea and weight loss. Three 24-hr stool collections were obtained during this period; three additional collections were also obtained during an interval when the patient was gaining weight and showing clinical improvement. The patient was readmitted to the hospital for a bout of diarrhea 6 weeks after complete clinical recovery. Twenty-four-hour stool collections were obtained on the Ist day, while the patient was on n.p.o. regimen and undergoing conventional parenteral fluid therapy. Another 24-hr collection was obtained on the 4th day of hospitalization, when the patient was fully recovered and consumed a diet that contained $12 \mathrm{~g}$ protein. An additional 24-hr collection, 2 months after recovery, was also obtained. In summary, this patient's stool collections were made during severe, protracted diarrhea that necessitated parenteral alimentation (periods of exacerbation and remission), during an isolated acute episode of diarrhea, and after complete recovery. Further data on the clinical aspects of this case and details regarding parenteral alimentation are beyond the scope of this paper. Information on the routine work-ups of patients is also omitted.

\section{Amino Acid Analysis}

A 1-g equivalent of homogenized stool sample was deproteinized by adding $1 \%$ picric acid $(1+4 \mathrm{v} / \mathrm{v})$. The mixture was centrifuged and the supernatant pipetted into a column of Dowex $2 \times 8\left(\mathrm{Cl}^{-}\right)$for the removal of picrate [29]. The column was washed six times with 5-ml aliquots of $0.01 \mathrm{~N} \mathrm{HCl}$ and the combined effluents were evaporated to dryness using a rotary evaporator. The samples were taken up in a known volume of citrate buffer, $\mathrm{pH}$ 2.2. Free amino acids were measured by an automatic amino acid analyzer [24]. Judged by the recovery of norleucine, used as an internal standard, reproducibility of the method was better than $95 \%$.

\section{Estimation of Protein}

A known amount of stool was precipitated by $10 \%$ trichloroacetic acid. The precipitate was washed twice with a $5 \%$ solution of this acid, and then dissolved in $0.1 \mathrm{~N} \mathrm{NaOH}$. Protein was determined on an aliquot by the method of Lowry et al. [17].

\section{Estimation of Total Nitrogen}

One milliliter of diluted homogenate representing $0.1 \mathrm{~g}$ native stool was placed in a micro-Kjeldahl flask. Concentrated sulfuric acid $(2 \mathrm{ml})$ and a catalyst mixture (2-4 mg) [4] were then added, and the mixture was digested until the solution was clear $(12-20 \mathrm{hr}$ 
brisk boiling). The contents were cooled, and nitrogen in the digested samples was determined as ammonia by ninhydrin according to the method of Jacobs [11].

\section{Results}

The results of the analyses are presented as means; upper and lower limits observed for each amino acid are given as well. Because of the relatively wide variation and the small number of samples, standard deviations are not given.

In Table I, the values for free amino acids in the stool of five 24-hr collections from five control infants are compared with the values for eight similar collections from six infants with diarrhea. In two infants with diarrhea, two pairs of consecutive 24-hr collections were obtained. In one pair, virtually no variation was observed from one day to the next ( 545 versus 546 $\mathrm{mg})$; the variation in the other pair was rather small $(1,310$ versus $1,500 \mathrm{mg})$. The values for total protein and nitrogen in the stool are also included in Table $I$.

In view of the numerous factors that might influence amino acid excretion in the stool (microbial flora, diet, etc.), the number of controls used in this study is obviously inadequate to establish normal excretion patterns. Control values are presented merely to show the general order of magnitude that can be expected. The primary significance of amino acid excretion in patients with diarrhea lies in its endogenous origin, rather than in quantitative comparison with control subjects.

In controls, amino acid excretion generally fell within a narrow range, even though these infants were on an ad libitum diet. In one control infant, the excretion of amino acid was relatively high $(327 \mathrm{mg} / 24 \mathrm{hr}$ ), but the bulk of this was made up of glutamic acid (over $200 \mathrm{mg}$ ). If this value for glutamic acid is replaced by the average value for the other control infants, the adjusted total amino acid excretion is then comparable to that in the other control subjects. On this basis, the total amino acid excretion in the stool of the five controls ranged from 57 to $131 \mathrm{mg} / 24 \mathrm{hr}$, with a mean value of 84 . Lysine made up more than onethird of this value.

The excretion of free amino acids by patients with acute diarrhea showed a great variation (312-1,500 $\mathrm{mg} / 24 \mathrm{hr}$, with a mean value of 900 ). In the patients with diarrhea, both protein and total nitrogen were elevated significantly as compared with the values for control subjects. The mean value for protein in patients with diarrhea was $670 \mathrm{mg} / 24 \mathrm{hr}$ as compared
Table $I$. Free amino acids, protein, and nitrogen levels in stool ${ }^{1}$

\begin{tabular}{|c|c|c|c|c|}
\hline \multirow{2}{*}{ Amino acid } & \multicolumn{2}{|c|}{$\begin{array}{l}\text { Diarrhea patients, } \\
\mathrm{mg} / 24 \mathrm{hr}\end{array}$} & \multicolumn{2}{|c|}{$\begin{array}{l}\text { Five controls, } \\
\mathrm{mg} / 24 \mathrm{hr}\end{array}$} \\
\hline & Mean & Range & Mean & Range \\
\hline Glutamic acid & 210.4 & $4.6-416.2$ & 8.5 & $6.0-13.0$ \\
\hline Aspartic acid & 44.5 & $5.0-181.5$ & 1.3 & $0.5-2.6$ \\
\hline Lysine & 94.4 & $38.1-160.0$ & 30.9 & $19.9-39.4$ \\
\hline Alanine & 121.4 & $12.6-502.1$ & 6.1 & $1.1-13.4$ \\
\hline Leucine & 86.2 & $39.3-174.0$ & 3.8 & $0.6-7.5$ \\
\hline Isoleucine & 37.5 & $13.4-87.7$ & 2.6 & $0.4-4.4$ \\
\hline Valine & 40.0 & $26.7-64.4$ & 3.8 & $0.6-8.1$ \\
\hline Serine & 42.9 & $0.4-155.4$ & 0.5 & $0.2-0.9$ \\
\hline Glycine & 36.6 & $1.3-100.3$ & 2.6 & $0.6-5.2$ \\
\hline Phenylalanine & 40.5 & $21.3-59.1$ & 8.4 & $0.7-22.6$ \\
\hline Tyrosine & 20.1 & $9.2-37.7$ & 4.0 & $1.2-6.9$ \\
\hline Threonine & 35.5 & $0.5-109.5$ & 0.8 & $0.3-1.7$ \\
\hline Histidine & 30.6 & $7.7-70.0$ & 3.4 & $3.0-3.7$ \\
\hline Proline & 44.2 & $3.2-111.6$ & 8.3 & $0.5-29.6$ \\
\hline Methionine & 20.4 & $3.4-69.8$ & 1.3 & $1.3-1.4$ \\
\hline Cystine & 11.7 & $2.8-21.2$ & 1.7 & $0.6-2.9$ \\
\hline Arginine & 15.3 & $1.0-34.5$ & 2.1 & $1.0-3.1$ \\
\hline Total amino acids 2 & 900.0 & $312.0-1500.0$ & 84.0 & $57.5-131.0$ \\
\hline Total protein & 670.1 & $142.0-2054.0$ & 174.7 & $110.0-312.6$ \\
\hline Total nitrogen & 1568.0 & $345.0-4000.0$ & 665.0 & $573.0-757.0$ \\
\hline
\end{tabular}

1 Twenty-four-hour fecal excretion of free amino acids, protein, and nitrogen of five control infants (ages 2.5-9 months) and from six infants with diarrhea (ages 5-20 months, total of eight collections).

2 The total is based on the overall amino acid excretion in each 24-hr collection, rather than a summation of the means or ranges for individual amino acids.

with $174 \mathrm{mg} / 24 \mathrm{hr}$ in controls, and the values for total nitrogen were 1,568 and $665 \mathrm{mg} / 24 \mathrm{hr}$, respectively.

Table II shows an increase in total amino acid excretion during exacerbation of diarrhea as compared with a period of clinical improvement (mean, 518 versus $172 \mathrm{mg} / 24 \mathrm{hr}$ ). Total nitrogen demonstrates a similar trend. The mean values for total protein during the two periods are comparable, but the range during remission was very wide (82-456 mg/24 hr). Although the mean for total nitrogen excretion during the remission period is very similar to that of controls, the mean values for total amino acids and total protein are almost double those of controls.

Amino acid excretion in the stool on the 2nd day of acute diarrhea amounted to $582 \mathrm{mg} / 24 \mathrm{hr}$, in contrast to $95 \mathrm{mg}$ on the fourth day after admission when the patient had recovered (Table III). Other values for the two periods, respectively, were 431 and $182 \mathrm{mg} / 24 \mathrm{hr}$ for total protein and 819 and $610 \mathrm{mg} / 24 \mathrm{hr}$ for nitrogen.

\section{Discussion}

The marked increase in the excretion of amino acids and other nitrogenous substances found in our patients with diarrhea is of particular significance, since the patients were not receiving anything by mouth and the loss was entirely from endogenous sources. 
Table II. Free amino acids, protein, and nitrogen in stool of a single patient on total parenteral alimentation for protracted diarrhea ${ }^{\mathbb{I}}$

\begin{tabular}{|c|c|c|c|c|c|c|}
\hline \multirow{3}{*}{ Amino acid } & \multicolumn{4}{|c|}{ Patient } & \multirow{2}{*}{\multicolumn{2}{|c|}{$\begin{array}{l}\text { Five controls, } \\
\mathrm{mg} / 24 \mathrm{hr}\end{array}$}} \\
\hline & \multicolumn{2}{|c|}{$\begin{array}{c}\text { During exacerbation of diarrhea, } \\
\mathrm{mg} / 24 \mathrm{hr}\end{array}$} & \multicolumn{2}{|c|}{$\begin{array}{c}\text { During clinical improvement, } \\
\mathrm{mg} / 24 \mathrm{hr}\end{array}$} & & \\
\hline & Mean & Range & Mean & Range & Mean & Range \\
\hline Glutamic acid & 129.3 & $72.1-227.4$ & 23.1 & $6.0-37.3$ & 8.5 & $6.0-13.0$ \\
\hline Aspartic acid & 36.3 & $23.8-56.8$ & 11.4 & $7.2-16.0$ & 1.3 & $0.5-2.6$ \\
\hline Lysine & 50.7 & $28.5-67.1$ & 29.0 & $5.3-52.1$ & 30.9 & $19.9-39.4$ \\
\hline Alanine & 35.0 & $24.4-43.6$ & 17.8 & $7.3-29.7$ & 6.1 & $1.1-13.4$ \\
\hline Leucine & 38.2 & $24.1-61.1$ & 11.6 & $2.4-23.4$ & 3.8 & $0.6-7.5$ \\
\hline Isoleucine & 20.7 & $15.3-29.7$ & 8.2 & $2.3-12.9$ & 2.6 & $0.4-4.4$ \\
\hline Valine & 9.7 & $9.7-9.7$ & 10.5 & $5.8-153$ & 3.8 & $0.6-8.1$ \\
\hline Serine & 27.5 & $24.3-30.2$ & 7.4 & $3.9-11.0$ & 0.5 & $0.2-0.9$ \\
\hline Glycine & 22.5 & $22.0-23.2$ & 12.8 & $9.9-16.7$ & 2.6 & $0.6-5.2$ \\
\hline Phenylalanine & 23.2 & $15.2-31.2$ & 9.7 & $7.2-16.0$ & 8.4 & $0.7-22.6$ \\
\hline Tyrosine & 9.3 & $4.1-14.0$ & 4.3 & $2.9-5.7$ & 4.0 & $1.2-6.9$ \\
\hline Threonine & 28.3 & $19.8-43.9$ & 6.6 & $3.9-11.0$ & 0.8 & $0.3-1.7$ \\
\hline Histidine & 36.3 & $25.5-54.2$ & 9.4 & $3.7-15.3$ & 3.4 & $3.0-3.7$ \\
\hline Proline & 17.9 & $10.8-24.1$ & 8.9 & $5.4-11.0$ & 8.3 & $0.5-29.6$ \\
\hline Methionine & 10.8 & $5.5-16.8$ & 5.6 & $1.1-13.4$ & 1.3 & $1.3-1.4$ \\
\hline Cystine & 55.7 & $55.7-55.7$ & 2.4 & $2.4-2.4$ & 1.7 & $0.6-2.9$ \\
\hline Arginine & 9.5 & $0.5-22.0$ & 3.5 & $3.5-3.5$ & 2.1 & $1.0-3.1$ \\
\hline Total amino acids ${ }^{2}$ & 518.0 & $470.5-608.0$ & 172.2 & $108.0-260.0$ & 84.0 & $57.5-131.0$ \\
\hline Total protein & 312.0 & $223.2-456.0$ & 308.5 & $82.6-456.0$ & 174.7 & $110.0-312.6$ \\
\hline Total nitrogen & 1010.0 & $757.0-1398.0$ & 656.0 & $174.0-987.0$ & 665.0 & $573.0-757.0$ \\
\hline
\end{tabular}

Twenty four-hour fecal excretion of free amino acids, protein and nitrogen of the patient during periods of remission (three collec. tions), compared with excretion during periods of exacerbation (three collections). Corresponding data on five control infants are also presented.

2 The total is based on the overall amino acid excretion in each 24-hr collection, rather than a summation of the means or ranges for individual amino acids.

Data on the level of amino acids of endogenous origin participating in digestion are not available for pediatric age groups, but the magnitude can be surmised from the figures reported for adults. In the normal adult, endogenous nitrogen taking part in digestion is believed to be approximately $2-3$ times the average protein intake. If animal experiments are taken into account, the participation of endogenous nitrogen in the process of digestion may be considerably greater. Nasset and Ju [20] has shown that, in rats, labeled nitrogen from administered casein is diluted in the gastrointestinal tract up to sevenfold by endogenous material. The finding that the bulk of amino acids present in the jejunum during digestion is of endogenous origin was also supported by test-meal experiments in dogs [18], which showed that intestinal amino acid composition did not vary substantially with the nature of the meal (zein, egg albumin, or mixture of sucrose and lard).

The major source of endogenous protein is the intestinal mucosa, which covers a large surface area and has a short half-life ( $36 \mathrm{hr})$. It has been estimated that in adults sloughing of intestinal mucosa contributes as much as $77-91 \mathrm{~g}$ protein every $24 \mathrm{hr}$ to the endogenous cycle [19]. Another important internal source of nitrogenous material is the digestive enzymes; in adults, these enzymes have been estimated to supply approximately $35 \mathrm{~g}$ protein $/ 24 \mathrm{hr}$ (protein content of digestive fluids, in grams per 24 hours: salivary, 4.5 ; gastric, 9.3; biliary, 1.0; pancreatic, 10.5; intestinal, 9.9) [26]. Under physiologic conditions, a significant amount of plasma protein leaks out into the gastrointestinal tract, is rapidly digested into constituent amino acids and largely reabsorbed [13]. Microorganisms, too, contribute to the amino acid content of the intestine. Antimicrobial therapy often employed in diarrhea probably reduces this amino acid supply.

Under normal circumstances, the bulk of nitrogenous material of endogenous origin is reabsorbed, mainly in the ileum. In contrast, exogenously supplied protein is reabsorbed mainly in the upper part of the intestinal tract. The normal adult excretes in the stool about $1 \mathrm{~g}$ nitrogen daily, approximately half of which is of bacterial origin. Our preliminary data indicate 
that normal infants under 1 year of age excrete roughly one-half of this amount, and that free amino acids contribute about $2 \%$ of the total fecal nitrogen.

In diarrhea, the contribution made by amino acids rises to $10 \%$ of the total excreted nitrogen (Table I). Diarrhea is thus associated with both an absolute and a relative increase in fecal amino acid excretion. Peptides were not measured in this study; it seems likely, however, that in diarrhea they are excreted in increased quantities.

In acute diarrhea, increased amino acid excretion of 10 -fold magnitude was observed (Table I). The signifcance of this finding may be questioned in view of the limited number of patients and controls. However, the elevation is corroborated by data from an additional patient who acted as his own control (Table III). The second column of Table III shows values obtained from stool collections on the fourth day of admission, when the patient ingested $12 \mathrm{~g}$ protein. His total amino acid excretion amounted to $95 \mathrm{mg} / 24 \mathrm{hr}$. Two months following this episode, an additional 24-hr collection was obtained and analyzed. The figures substantially agree with those of the second column, and i. e consistent with control values obtained for healthy infants. Excretion of protein and total nitrogen in this patient during recovery periods is also in substantial agreement with corresponding values from normal controls. This part of the study explicitly demonstrates the following. ( $I$ ) During diarrhea there was a substantial loss of amino acids (from 95 to $582 \mathrm{mg} / 24 \mathrm{hr}$ ). (2) Diarrhea was associated with an increase in the output of protein from 182 to $431 \mathrm{mg} / 24 \mathrm{hr}$; this increase, although significant, was not of the same magnitude as that observed for the amino acids. (3) There was a definite, although smaller increase in total nitrogen excretion (from 610 to $819 \mathrm{mg} / 24 \mathrm{hr}$ ). (4) In diarrhea, the loss of nitrogenous substances derived from endogenous sources.

The circumstances under which such losses of protein and amino acids occur, as well as the likelihood of the persistence of the loss over the course of diarrhea, are particularly ominous. The patients are generally deprived of oral intake, the mere introduction of glucose and water into an unprepared digestive tract precipitates further loss of nitrogenous material, badly needed for regeneration of intestinal mucosa and synthesis of digestive enzymes. These losses may lead to protein deficiency. Such deficiency per se is known to cause malabsorption of carbohydrate [3] and fat [22], atrophy of intestinal mucosa [12, 27], and interference with the svnthesis of digestive enzymes $[2,15,16]$.
Table III. Free amino acids, protein, and nitrogen in stool of the same patient during episode of acute diarrhea and after full recovery ${ }^{1}$

\begin{tabular}{|c|c|c|c|c|}
\hline \multirow[b]{2}{*}{ Amino acid } & \multicolumn{2}{|c|}{ Patient } & \multicolumn{2}{|c|}{$\begin{array}{c}\text { Five controls, } \\
\mathrm{mg} / 24 \mathrm{hr}\end{array}$} \\
\hline & $\begin{array}{l}\text { Acute } \\
\text { diarrhea, } \\
\mathrm{mg} / 24 \mathrm{hr}\end{array}$ & $\begin{array}{l}\text { Recovery, } \\
\mathrm{mg} / 24 \mathrm{hr}\end{array}$ & Mean & Range \\
\hline Glutamic acid & 22.2 & 6.8 & 8.5 & $6.0-13.0$ \\
\hline Aspartic acid & 8.1 & 7.0 & 1.3 & $0.5-2.6$ \\
\hline Lysine & 72.3 & 4.1 & 30.9 & $19.9-39.4$ \\
\hline Alanine & 125.4 & 12.6 & 6.1 & $1.1-13.4$ \\
\hline Leucine & 93.6 & 8.0 & 3.8 & $0.6-7.5$ \\
\hline Isoleucine & 30.9 & 4.9 & 2.6 & $0.4-4.4$ \\
\hline Valine & 58.8 & 5.8 & 3.8 & $0.6-8.1$ \\
\hline Serine & 48.6 & 4.1 & 0.5 & $0.2-0.9$ \\
\hline Glycine & 51.3 & 13.2 & 2.6 & $0.6-5.2$ \\
\hline Phenylalanine & 15.9 & 4.8 & 8.4 & $0.7-22.6$ \\
\hline Tyrosine & Overlap & 19.5 & 4.0 & $1.2-6.9$ \\
\hline Threonine & None & 4.3 & 0.8 & $0.3-1.7$ \\
\hline Histidine & 42.0 & Overlap & 3.4 & $3.0-3.7$ \\
\hline Proline & 3.6 & None & 8.3 & $0.5-29.6$ \\
\hline Methionine & 8.1 & Trace & 1.3 & $1.3-1.4$ \\
\hline Cystine & Trace & Trace & 1.7 & $0.6-2.9$ \\
\hline Arginine & 1.5 & None & 2.1 & $1.0-3.1$ \\
\hline Total amino acids & 582.0 & 95.0 & 84.0 & $57.5-131.0$ \\
\hline Total protcin & 431.0 & 182.0 & 174.7 & $110.0-312.6$ \\
\hline Total nitrogen & 819.0 & 610.0 & 665.0 & $573.0-757.0$ \\
\hline
\end{tabular}

1 Twenty-four-hour fecal excretion of amino acids, protein, and nitrogen of patient described in Table II readmitted with acute diarrhea 6 weeks following recovery from prolonged illness. Values obtained during acute episode are compared with corresponding data obtained 4 days later when patient was fully recovered (single stool collection) and with controls.

Aside from their obvious importance in protein digestion, the intestinal mucosa and digestive enzymes have special significance in the protein economy. Because they are themselves largely made up of protein, and because of their large bulk and rapid turnover, the mucosa and digestive enzymes may well be unusually vulnerable to the early stages of protein deficiency. Impeded regeneration of mucosa and synthesis of enzymes in turn would lead to further impairment of the available amino acid supply. It is thus our contention that acute diarrhea of infants, protracted beyond a week or so, sets in motion a vicious cycle in which accelerated protein depletion further hampers digestion and absorption. Attempts to counter starvation by premature oral feeding only result in further protein depletion ultimately turning a protracted state into an intractable one.

If intractable diarrhea, as we postulate, is the result of acute protein deficiency, then the condition should be amenable to the introduction of amino acid solution through the intravenous route. Total parenteral alimentation provides such an approach, and its effectiveness in the cure of intractable diarrhea has been documented recently in an increasing number of reports $[5,6,10,14,25,28]$. Table IV summarizes pub- 
Table IV. Protracted diarrhea treated by total parenteral alimentation

\begin{tabular}{|c|c|c|c|c|}
\hline Reference & $\begin{array}{l}\text { No. of } \\
\text { cases }\end{array}$ & Ages & \multicolumn{2}{|c|}{$\begin{array}{c}\text { Duration of } \\
\text { parenteral alimentation }\end{array}$} \\
\hline Filler et al. 1969 [6] & 2 & $\begin{array}{l}56 \text { days } \\
65 \text { days }\end{array}$ & \multicolumn{2}{|c|}{$\begin{array}{l}44 \text { days } \\
39 \text { days }\end{array}$} \\
\hline Dudrick et al., 1969 [5] & 1 & Neonate & \multicolumn{2}{|c|}{14 days } \\
\hline Sherman et al., 1971 [25] & 4 & $\begin{array}{l}3 \text { months } \\
2 \text { months } \\
2 \text { months } \\
8 \text { months }\end{array}$ & $\begin{array}{l}56 \\
38 \\
40 \\
35\end{array}$ & $\begin{array}{l}\text { lays } \\
\text { days } \\
\text { days } \\
\text { days }\end{array}$ \\
\hline $\begin{array}{l}\text { Keating and Ternberg, } \\
1971[14]\end{array}$ & 9 & Not specified & \multicolumn{2}{|c|}{$\begin{array}{l}35 \text { days } \\
14-37 \text { days }\end{array}$} \\
\hline \multirow[t]{2}{*}{$\begin{array}{l}\text { Stegink and Baker, } 1971 \\
\text { [28] }\end{array}$} & 3 & $\begin{array}{l}50 \text { days } \\
13 \text { days } \\
93 \text { days }\end{array}$ & \multicolumn{2}{|c|}{$\begin{array}{r}2 \text { days } \\
2 \text { days } \\
54 \text { days }\end{array}$} \\
\hline & & & i.v. only & Oral + i.v. \\
\hline $\begin{array}{l}\text { Hyman et al., } 1971 \\
\quad[10]\end{array}$ & 3 & $\begin{array}{l}10 \text { weeks } \\
2 \text { weeks } \\
1 \& 2 \\
\text { months }\end{array}$ & $\begin{array}{c}4 \text { weeks } \\
3 \text { weeks } \\
2+6 \\
\text { weeks }\end{array}$ & $\begin{array}{l}6 \text { weeks } \\
7 \text { weeks }\end{array}$ \\
\hline Total & 22 & & & \\
\hline Range & Neonate- & -8 months & 2 days -56 & days \\
\hline
\end{tabular}

lished data on 22 infants with protracted diarrhea who were treated by total parenteral alimentation. The diagnostic criteria generally agree with those of Avery et al. [1]. The average length of therapy was about 4 weeks, with a range of 2 to 56 days. Our own limited experience with parenteral alimentation parallels these findings [7]. We have treated six patients with protracted diarrhea by total parenteral alimentation, with uniformly excellent results as judged by weight gain and ultimate recovery. The duration of parenteral alimenation in these patients varied from 8 to 24 days, with a mean duration of 17 days. The additional patient, whose fecal amino acid excretion has been reported in Table II, had to stay on this regimen for 85 days. The weight gain and ultimate recovery, as reflected in Figure 1, were gratifying.

It may be argued that the effectiveness of parenteral alimenation is simply due to leaving the gastrointestinal tract at rest and allowing it time to recuperate. But such a rest-indeed, on an extended scale beyond one life-span of intestinal mucosa-has already been granted by conventional fluid therapy and n.p.o. regimen, without enabling the gastrointestinal tract to resume its physiologic function. In this situation, in which the resting organ is also responsible for the absorption of the very nutrient it needs for recuperation, the principle of "rest for restoration" has limited value. It is the amino acids of the infusate for total parenteral alimentation that provide the building blocks for the proper synthesis of digestive enzymes and intestinal mucosa. Adequate provision of other nutrients, especially fat or carbohydrates, no doubt en- hances proper utilization of amino acids, as shown in animal experiments [9].

The practical questions remaining to be answered are in respect to prevention of intractable diarrhea. How long does it take for acute diarrhea to become intractable? How can this downhill course be prevented?

Unfortunately, there is at present no reliable way of estimating the state of the body's protein economy, nor of detecting protein deficiency in its early stages.

We know of no nitrogen pool in the body which plays a role in the protein economy analogous to that performed by glycogen in carbohydrate metabolism. Free amino acids of the tissues, generally considered as currency in the economy of protein, constitute only a very small proportion of total body protein. The total free amino acids of plasma, generally accessible to analysis, constitute only about $0.01 \%$ of the total body protein and provide no clue to a state of acute protein deficiency.

On the other hand, the pattern of amino acid excretion in the stool may provide a guide to the condition of intestinal mucosa. Although all the amino acids showed elevated excretion, the increase varied widely with individual amino acids ranging from 5 to 85 -fold. Threonine, serine, leucine, glutamic acid, and aspartic acid were elevated beyond 20 -fold (Table I). The emerging pattern should be studied when a greater volume of statistically significant data on various types and stages of diarrhea becomes available.

The increases in glutamic and aspartic acids may lend themselves to special interpretation. Experiments in dogs, cats, and rabbits show that the intestinal absorption of glutamic and aspartic acids differs from that of all other amino acids [21, 23, 30]. Intestinal cells are responsible for transamination of these amino acids of chyme, and for the formation of glutathione. In humans, too, circumstantial evidence suggests that ingested glutamic acid follows a path different from all other amino acids [8]. If in humans, too, the mucosal walls are responsible for the metabolism of glutamic acid present in the chyme, then increased excretion of this substance may provide a sensitive test for evaluating the integrity of intestinal mucosa. One of our control infants excreted over $200 \mathrm{mg}$ glutamic acid in a single 24-hr period; the following day the infant exhibited diarrhea. Only further studies could establish whether this finding was fortuitous or whether glutamic acid excretion is a reliable index to the state of intestinal mucosa.

Since the state of protein economy, the condition of 

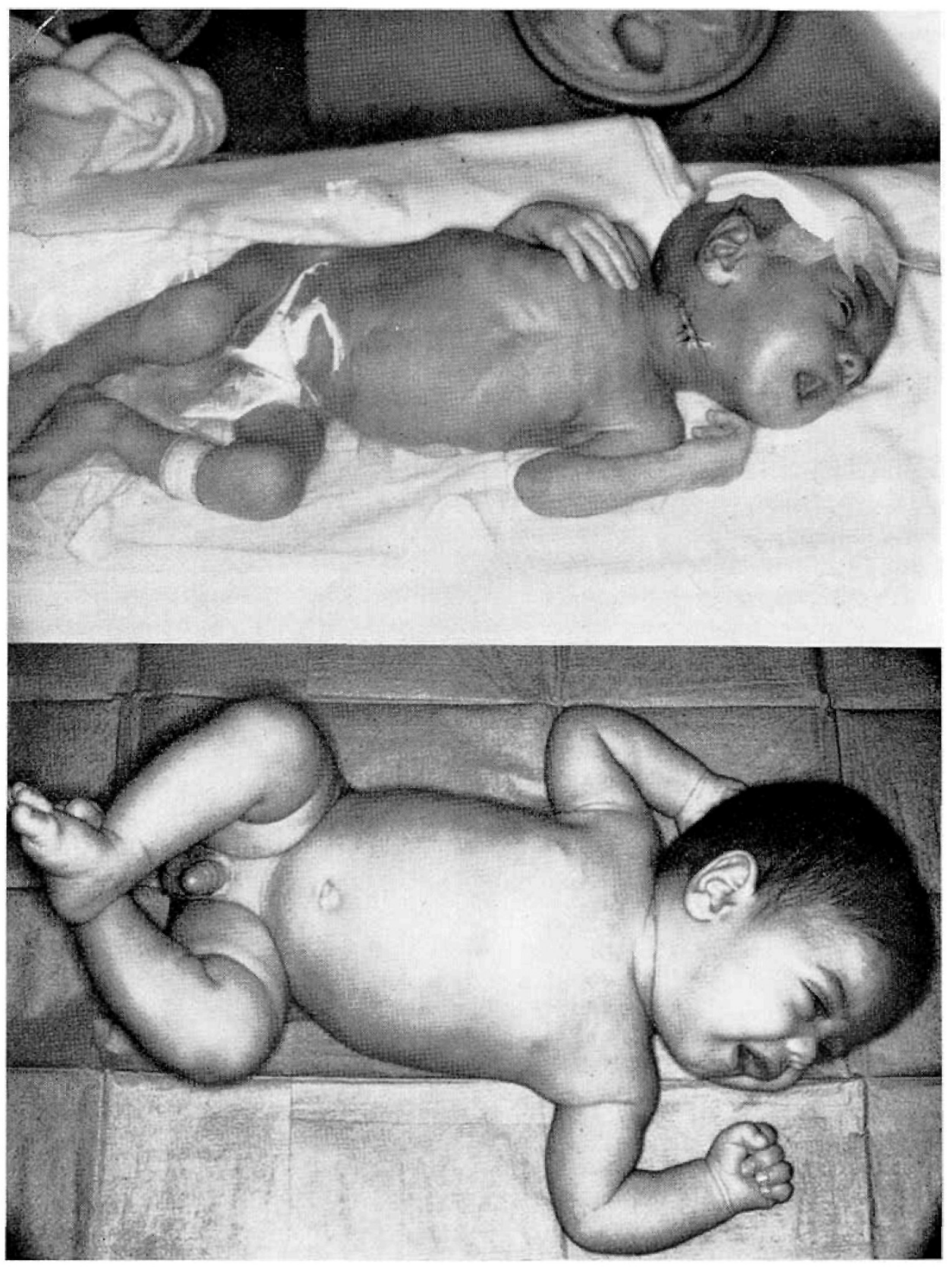

Fig. 1. Photographs of the patient within 1 week after institution of parenteral alimentation, and after complete recovery.

intestinal mucosa, and the exact point at which the downhill course enters into an intractable stage cannot be ascertained, it is the better part of wisdom to introduce amino acid solutions as early as possible. Based on the life-span of intestinal mucosa, full recuperation should not take more than 3 or 4 days, provided that the original cause of acute diarrhea has been eliminated. We have therefore instituted the policy of ad- ministering an amino acid solution [32] by peripheral vein at the rate equivalent to $\mathrm{I} \mathrm{g}$ protein $/ \mathrm{kg}$ body $\mathrm{wt} / 24 \mathrm{hr}$ in all cases in which diarrhea has progressed beyond 3 days. This, of course, requires a corresponding reduction in the volume of glucose solution conventionally administered. Total parenteral alimentation is reserved for cases in which diarrhea has persisted for more than 2 weeks. 


\section{Summary}

Protein depletion is introduced as a unitary concept in the progression of acute infantile diarrheas into a protracted or intractable stage. It has been shown that in acute infantile diarrhea significant amounts of endogenous nitrogen are lost through the stool. Accumulated loss beyond a week or so may interfere with regeneration of intestinal mucosa and the synthesis of digestive enzymes. The success of total parenteral alimentation in the management of intractable diarrhea supports this theory. As a relatively simple preventive measure, the administration of amino acid solution by peripheral vein, concomitantly with glucose, is suggested in the management of the early stages of infantile diarrhea.

\section{Addendum}

The patient described in Figure I has recently been reevaluated at 2 years of age. Growth and development were found to be well within normal limits.

\section{References and Notes}

1. Avery, G. B., Villavicencio, O., Lilly, J. R., and Randolph, J. G.: Intractable diarrhea in early infancy. Pediatrics, 41: 712 (1968).

2. Bowie, M. D., Barbezat, G. O., and Hansen, J. D. L.: Carbohydrate absorption in malnourished children. Amer. J. Clin. Nutr., 20: 89 (1967).

3. Bowie, M. D., Brinkman, G. L., and Hansen, J. D. L.: Acquired disaccharide intolerance in malnutrition. J. Pediat., 66: 1083 (1965).

4. Chrbnell, A. C., Rees, M. W., and Williams, E. F.: Total nitrogen content of egg-albumin and other proteins. Biochem. J., 37: 354 (1943).

5. Dudrick, S. J., Wilmore, D. W., Vars, H. M., and Rhoads, J. E.: Can intravenous feeding as the sole means of nutrition support growth in the child and restore weight loss in the adult? Ann. Surg., 169: 974 (1969).

6. Filler, R. M., Eraklis, A. J., Rubin, V. G., and Das, J. B.: Long-term total parenteral nutrition in infants. New Engl. J. Med., 281: 589 (1969).

7. Ghadimi, H., Abaci, F., Kumar, S., and Rathi, M.: Biochemical aspects of intravenous alimentation. Pediatrics, 48: 955 (1971).

8. Ghadimi, H., And Kumar, S.: Current status of monosodium glutamate. Amer. J. Clin. Nutr., 25: 643 (1972).

9. Heller, L.: Clinical and experimental studies on complete parenteral nutrition. Scand. J. Gastroenterol., 4: Suppl. 3 (1969).

10. Hyman, C. J., Retter, J., Rodnan, J., and Drash, A. L.: Parenteral and oral alimentation in the treatment of nonspecific protracted diarrheal syndrome in infancy, J. Pediat., 78: 17 (1971).

11. JACOBS, S.: Determination of nitrogen in protein by means of indanetrione hydrate. Nature, 183: 262 (1959).
12. James, W. P. T.: Effects of protein-calorie malnutrition on intestinal absorption. Ann. N.Y. Acad. Sci., 176: 244 (1971).

13. Jeffries, G. H., Holman, H. R., and Sleisenger, M. H.: Plasma proteins and the gastrointestinal tract. New Engl. J. Med., 266: 652 (1962).

14. Keating, J. P., and Ternberg, J. L.: Amino acid-hypertonic glucose treatment for intractable diarrhea in infants. Amer. J. Dis. Child., 122: 226 (197l).

15. Knudsen, K. B., Bellamy, H. M., Lecocg, F. R., Bradley, M., and WeLSH, J. D.: The influence of fasting and refeeding on jejunal disaccharidases. Clin Res., 14: 300, 1966.

16. Kumar, V., Chase, H. P.: Progressive protein undernutrition and intestinal enzyme activities in monkeys, Amer. J. Clin. Nutr., 25: 485 (1972).

17. Lowry, O. H., Rosebrough, H. J., FarR, A. L., and Randall, R. J.: Protein measurement with the Folin-phenol reagent. J. Biol. Chem., 193: 265 (1951).

18. NASSET, E. S.: Role of the digestive tract in the utilization of protein and amino acids. J. Amer. Med. Ass., 164: 172 (1957).

19. NASSET, E. S.: Role of the digestive system in protein metabolism. Fed. Proc., 24: 953 (1965).

20. NASSET, E.S.AND JU, J S.: Mixture of endogenous and exogenous prein in the alimentary tract. J. Nutr., 74: 461 (1961).

21. Neame, K. D., and Wiseman, G.: The transamination of glutamic and aspartic acids during absorption by the small intestine in the dog lin vivo. J. Physiol., 135: 442 (1957).

22. Oliveria, J. E. D., ANd Rolando, E.: Fat absorption studies in malnourished children. Amer. J. Clin. Nutr., 15: 287 (1964).

23. Peraino, C., And Harper, A. E.: Observations on the protein digestion in yivo. Free amino acids in blood plasma of rats force-féd zein, caseñ =or their respective hydrolysates. J. Nutr., 80: $270(1963)$

24. ATEZ; K. A AND MoRRIS, L. A.: A modified procedure for autonatic andysis of amino acids. Ann. Biochem., $L: 187$ (1960).

25. Sherman, J. O., Egan, T., and Macalad, F. V.: Parenteral hyperalimentation: A useful surgical adjunct. Surg. Clin. N. Amer., 51: 37 (1971).

26. SPencer, R. P.: "The Intestinal Tract: Structure, Function, and Pathology in Terms of the Basic Sciences," p. 307. (Charles C. Thomas, Springfield, Ill., 1960).

27. Stanfield, J. P., Hutt, M. S. R., and Tunnicliffe, R.: Intestinal biopsy in kwashiorkor. Lancet, $i i: 519$ (1965).

28. STEGINK, L. D., AND BAKER, G. L.: Infusion of protein hydrolysates in the newborn infant: Plasma amino acid concentrations. J. Pediat., 78: 595 (1971).

29. SteIn, W. H., AND MOORE, S.: Free amino acids of human blood plasma, J. Biol. Chem., 211: 915 (1954).

30. Wiseman, G.: Absorption from the Intestine. (Academic Press, New York, 1964).

31. Elemental diet, Eaton Laboratories, Norwich, N.Y.

32. The solution we use is GF-3 (Ghadimi Formula 3) containing 11 amino acids (8 essential); it has an osmolarity of 371 mosmol/liter, is equivalent to $5.2 \mathrm{~g}$ protein $/ 100 \mathrm{ml}$, and is administered at the rate of $1 \mathrm{~g} / \mathrm{kg}$ body wt $/ 24 \mathrm{hr}$.

33. Requests for reprints should be addressed to: Dr. H. GHAdrm, M.D., Methodist Hospital of Brooklyn, 506 Sixth St., Brooklyn, N. Y. 11215 (USA).

34. Accepted for publication November 22, 1972. 